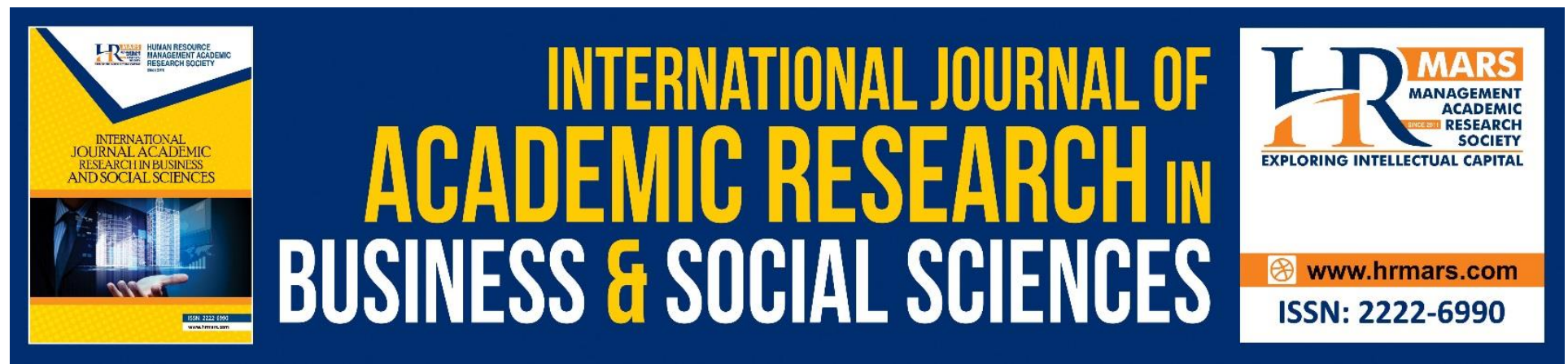

\title{
Students' Knowledge and Attitudes about the Gap Year Programme: A Study at a Public University in Malaysia
}

\section{Suriani Abdul Hamid, Suzyanty Mohd Shokory, Marinah Awang}

To Link this Article: http://dx.doi.org/10.6007/IJARBSS/v9-i2/5619

DOI: $\quad 10.6007 /$ IJARBSS/v9-i2/5619

Received: 17 Jan 2019, Revised: 25 Feb 2019, Accepted: 09 March 2019

Published Online: 12 March 2019

In-Text Citation: (Hamid, Shokory, \& Awang, 2019)

To Cite this Article: Hamid, S. A., Shokory, S. M., \& Awang, M. (2019). Students' Knowledge and Attitudes about the Gap Year Programme: A Study at a Public University in Malaysia. International Journal of Academic Research in Business and Social Sciences, 9(2), 826-838.

Copyright: (C) 2019 The Author(s)

Published by Human Resource Management Academic Research Society (www.hrmars.com)

This article is published under the Creative Commons Attribution (CC BY 4.0) license. Anyone may reproduce, distribute, translate and create derivative works of this article (for both commercial and non-commercial purposes), subject to full attribution to the original publication and authors. The full terms of this license may be seen

at: $\underline{\text { http://creativecommons.org/licences/by/4.0/legalcode }}$

$$
\text { Vol. 9, No. 2, 2019, Pg. } 826 \text { - } 838
$$

Full Terms \& Conditions of access and use can be found at http://hrmars.com/index.php/pages/detail/publication-ethics 


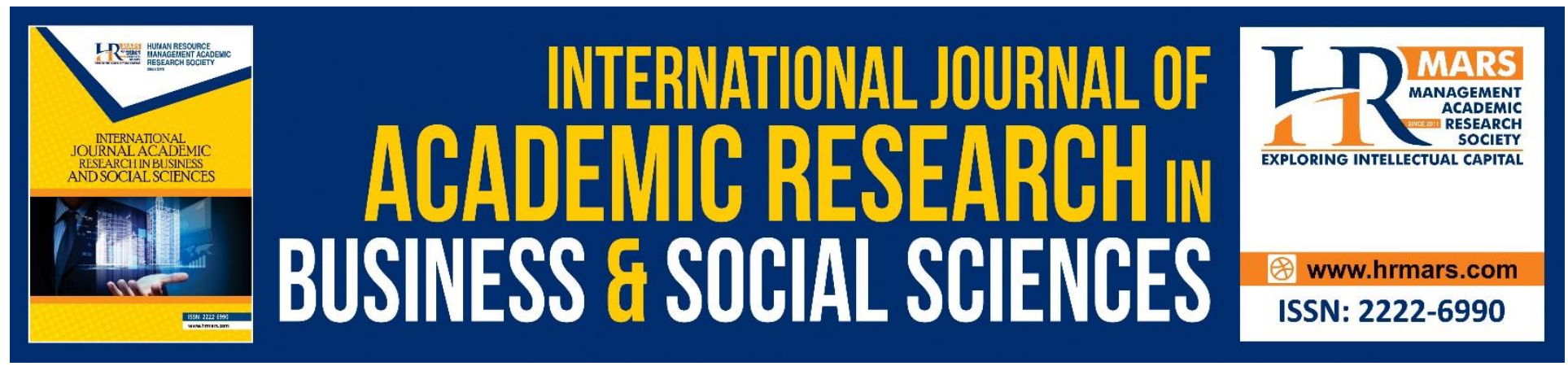

\title{
Students' Knowledge and Attitudes about the Gap Year Programme: A Study at a Public University in Malaysia
}

\author{
Suriani Abdul Hamid, Suzyanty Mohd Shokory, Marinah Awang \\ Universiti Pendidikan Sultan Idris, Malaysia
}

\begin{abstract}
This study seeks to understand students' knowledge and attitudes about a Gap Year programme at a public university in Malaysia. A survey questionnaire was distributed to a sample of 900 students representing all the 9 faculties at the university. The data analysis was conducted using the Statistical Packages for Social Science (SPSS) involving descriptive analysis (frequency and percentage). The results showed that the students had limited knowledge about the Gap Year programme. Despite the students' limited knowledge, their attitudes towards the programme was positive. The findings of the study are expected to add to the existing literatures regarding the Gap Year and provide empirical evidence about the Gap Year programme in the Malaysian context. Additionally, the findings are expected to provide useful insights for the university and the Ministry of Education about the newly launched Gap Year programme. Thus, more effective strategies can be developed, and the ministry's aspiration to produce holistic, balanced and entrepreneurial graduates can be realized.
\end{abstract}

Keywords: Gap Year, Knowledge, Attitude, Public University, Malaysia

\section{Introduction}

In January 2017, the Minister of Higher Education announced the Gap Year programme, which allows students in tertiary education who are in their second year onwards to take a year or two semesters off their formal education for their personal growth (Ministry of Higher Education Malaysia, 2017). The Gap Year programme is part of Shift 1 of the Malaysian Education Blueprint 2015-2025 (Higher Education), with the objective of producing holistic, balanced and entrepreneurial graduates (Malaysia Education Malaysia, 2015). There are three types of Gap Year programmes introduced by the ministry, namely the National Service Volunteer programme, the Volunteer programme and the general Gap Year programme. Under the 
National Service Volunteer Gap Year programme, students will be attached for one year at a uniformed agency such as armed forces, police, civil defence or maritime enforcement agency. Two universities, i.e. Universiti Teknolgi MARA (UITM) and Universiti Kebangsaan Malaysia (UKM) are the pioneer for this project (Ministry of Higher Education Malaysia, 2017). On the other hand, The Gap Year programme (Volunteer) is where 7 pioneer universities collaborate with participating agencies, for example, Universiti Utara Malaysia collaborates with Social Welfare Department, Universiti Pendidikan Sultan Idris collaborates with Ministry of Education and Perak Education Department, and Universiti Sains Islam Malaysia collaborates with Islamic Relief Malaysia (Ministry of Higher Education Malaysia, 2017). Students who choose this programme will do volunteer work with these agencies for a period of 3 months to 1 year. Unlike the first 2 programmes which are very structured, the third programme is general where students can take time out from the university to get involved in sports activities, entrepreneurship, increase their skills, travel etc, for a minimum of one semester and a maximum of one academic calendar (Ministry of Higher Education Malaysia, 2017).

Gap Year is a new concept in Malaysia, but the idea has been growing and developing in western countries for at least three decades (Wu, Pearce, Huang \& Fang, 2015). In the United States for example, an increasing number of universities are encouraging gap years as well as providing deferral-friendly admissions options (Guidi, 2018). Among the initiatives include those by Tufts University's $1+4$ Bridge Year, Princeton's Bridge Year, the University of North Carolina's Global Gap Year, Elon University's Global Pathfinders, and St. Norbert's College Gap Experience are inhouse bridge year programs available to a limited number of incoming freshman who apply (Guidi, 2018). Not only in the United States (Grose, 2010; Tucker, 2012 \& Guidi, 2018), existing studies on Gap Year students have attempted to understand this phenomenon and most of these studies have been conducted in the UK (Abidi, 2002; Heath, 2007), Australia (Birch \& Miller, 2007) and getting popular in other countries as well, where some research has also been conducted in South Africa (Nieman, 2013) and China (Wu, Pearce, Huang \& Fang, 2015).

The Gap Year phenomenon has been around in the above mentioned countries for decades, and most of the studies have focused on the students' experiences, their motivating factors, the benefits and drawbacks of the Gap Year experience, and their experience towards career decision-making (Haeth, 2007; Nieman, 2013; O'Shea, 2011; Wu, Pearce, Huang \& Fang, 2015. In Malaysia, where the Gap Year is a very new concept and was only started in September 2017, to the researcher's knowledge, very limited evidence of the Gap Year can be found in the Malaysian context. Therefore, the need to understand students' knowledge about the programme, and their attitudes regarding the programme are the critical issues that need to be addressed. If we understand the Gap Year from the students' perspectives, this will help universities and the ministry to provide support and guidance to the young people to pursue their educational and career goals. It may also assist the universities and the ministry to develop the appropriate strategies. Therefore, a study to examine these issues is clearly warranted. 


\section{Literature Review}

The Gap Year is defined in a number of ways. Some defined it as a break in educational career that is usually taken between leaving school and beginning to study at a university (Jones, 2004; King, 2011). Other researchers refer to it as taking time out between high school and college, sometimes during college (Hulstrand,2010, Torpey, 2009) or after college (Torpey, 2009). Stehlik (2010) uses the definition by UK's Department of Education and Skills, which describes it as a period of 3 to 24 months, during which the individual takes time out from a formal work or education trajectory. A similar length of time was also offered earlier by Jones (2004). Heath (2006) refers to the Gap Year as taking time out before engaging in a more settled career. Based on these definitions, although they may differ in time length or when Gap Year is taken, in essence, the Gap Year is where students departing from standard education move from high school to tertiary education or during tertiary education and then making another transition back in. A gap year can be structured or unstructured with a combination of voluntary work locally or overseas (Nieman, 2013). The purpose of the Gap Year is to open students' mind and create opportunities for their journey through tertiary education and their lives after that (Haighler \& Nelson, 2005) and it should prepare students to develop particular knowledge, skills, abilities through hands-on experience (Cremin, 2007)

Taking a gap year has been popular in the UK and Australia. For example, in the UK since 2002, $2.2 \%$ of university applicants had chosen to defer their acceptance to university to take a gap year (Abidi, 2004), while Heath (2007) proposed that approximately 45,000 young people took a Gap Year each year in that country. A similar trend can be seen in Australia where $11 \%$ of high school graduates chose to take a Gap Year (Birch and Miller, 2007). Taking a gap year between high school and tertiary education is also popular in the United States (Grose, 2010: Tucker, 2012) and the idea gained momentum when the oldest daughter of the previous President Barack Obama announced her plan to take a gap year before starting at Harvard University (US Fed New Service, 2017). It has also gained popularity in other parts of the world such as in South Africa (Nieman, 2013) and China (Wu, Pearce, Huang \& Fang, 2015).

The Gap Year can be rewarding but it also has drawbacks. It is a great way for students to learn about their individual interests and their career pursuits, help students mature and choose the right path (Hulstrand, 2010). Students involved in the Gap Year can acquire a range of benefits from the transformative experience including the acquisition of soft skills and cross-cultural experience in a host country (Jones, 2005), significant gains in personal, civic, moral and intellectual development (O'Shea, 2011), developing confidence, maturity and independence (King, 2011). It also has its drawbacks. Postponing study which takes them off from the traditional path sometimes makes it challenging for the students to get back and they do not graduate on time as their peers do (Hulstrand, 2010) 
INTERNATIONAL JOURNAL OF ACADEMIC RESEARCH IN BUSINESS AND SOCIAL SCIENCES

Vol. 9, No. 2, Feb, 2019, E-ISSN: 2222-6990 (C) 2019 HRMARS

\section{Objectives of the Study}

Realizing the critical needs as discussed earlier, this study seeks to address the following objectives:

1. To investigate students' knowledge about the Gap Year programme.

2. To investigate students'attitudes towards the Gap Year programme.

\section{Methodology}

The data was collected through a questionnaire survey. In the knowledge section, the questions directly measure students' knowledge about the gap year programme. Students were given some description about each type of Gap Year programme. The analysis to the knowledge questions were evaluated based on correctness of the answers. In the next section, the students were asked about their attitudes towards the programme. The questions on attitude employed the Likert scale of 5 rates of 1 (strongly disagree), 2(disagree), 3(neutral), 4(agree) and 5(strongly agree). A total of 900 questionnaires were distributed to students from all the 9 faculties at the university, where 887 questionnaires were completed and utilised for the analysis. The data was analysed using descriptive statistics.

\section{Results}

Table 1 shows the results of the demographic profile of the respondents.

Table 1: Demographic profile

\begin{tabular}{llcc}
\hline Demographic profile & Category & Frequency & Percentage (\%) \\
& & & \\
\hline Gender & Male & 285 & 32.1 \\
& Female & 602 & 67.9 \\
Ethnicity & Malay & 668 & 75.3 \\
& Chinese & 48 & 5.4 \\
& Indian & 37 & 4.2 \\
& Bumiputra Sabah/Sarawak & 134 & 15.1
\end{tabular}

\section{Knowledge}

Students were first asked if they knew about the Gap Year programme. As illustrated in Table 2, more than half of the students (61.7\%) did not know about the existence of the Gap Year programme in Malaysian universities. 
Table 2: Knowledge

\begin{tabular}{lcccc}
\hline & Frequency & Percent & Valid Percent & $\begin{array}{c}\text { Cumulative } \\
\text { Percent }\end{array}$ \\
\hline Yes & 340 & 38.3 & 38.3 & 38.3 \\
No & 547 & 61.7 & 61.7 & 100.0 \\
Total & 887 & 100.0 & 100.0 &
\end{tabular}

Students who knew about the Gap programme were asked to indicate the sources of information. The findings are shown in Figure 1.

Figure 1: Sources of information about the Gap Year programme

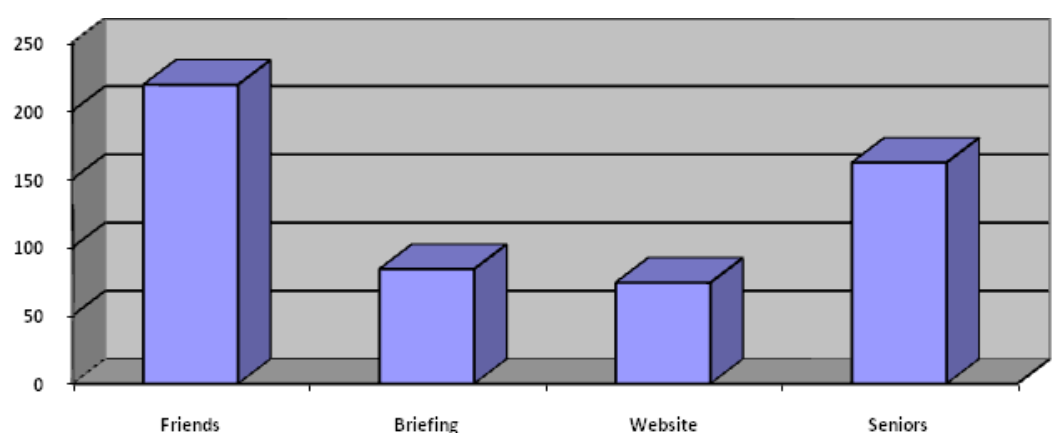

As illustrated in Figure 1, the highest source of information was from friends $(n=219)$, followed by seniors ( $n=162)$, university briefing $(n=84)$ and university website $(n=74)$.

As discussed in the literature section, there are three types of Gap Year programmes introduced by the ministry, namely the National Service Volunteer programme, the Volunteer programme and the general Gap Year programme. The first section asked questions about the students' knowledge of the National Service Volunteer programme. Respondents were asked about the agencies that students can be attached under National Service Volunteer programme. The results are illustrated in Figure 2. 


\section{Figure 2: Agencies for National Service Volunteer programme}

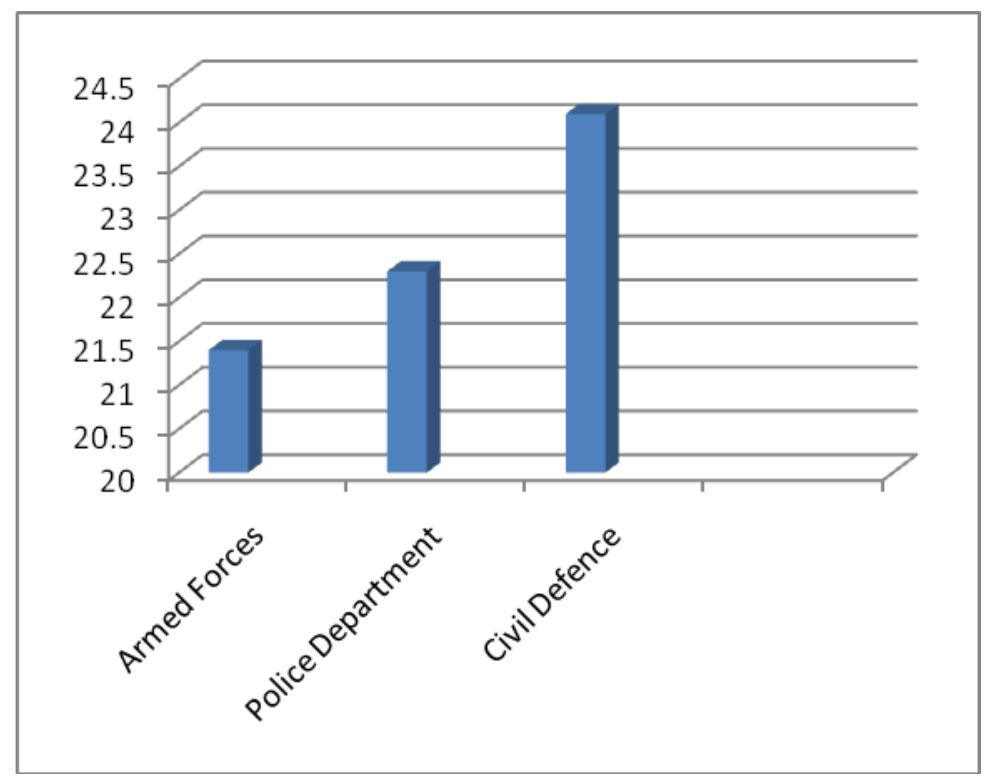

As illustrated in Figure 2, only 21.4\% $(n=190)$ knew that they could be attached to the Armed Forces for the Gap Year programme. 22.3\% ( $n=198)$ knew that the attachment could be done at the Police Department and $24.1 \%(n=214)$ of the respondents knew they could be attached to the Civil Defence for the Gap Year National Service programme.

Students were then asked to name the two universities which become the pioneer for the National Service Volunteer programme. Only 2\% $(n=18)$ students gave the correct answers i.e. Universiti Teknolgi MARA (UITM) and Universiti Kebangsaan Malaysia (UKM).

The next section focuses on the knowledge about the Volunteer programme. The first question investigated students' knowledge about the length of the volunteer programme. They were given four options of answers for the programme length. The finding is illustrated in Figure 3. 
INTERNATIONAL JOURNAL OF ACADEMIC RESEARCH IN BUSINESS AND SOCIAL SCIENCES Vol. 9, No. 2, Feb, 2019, E-ISSN: 222 2-6990 @ 2019 HRMARS

\section{Figure 3: Knowledge about the Volunteer programme}

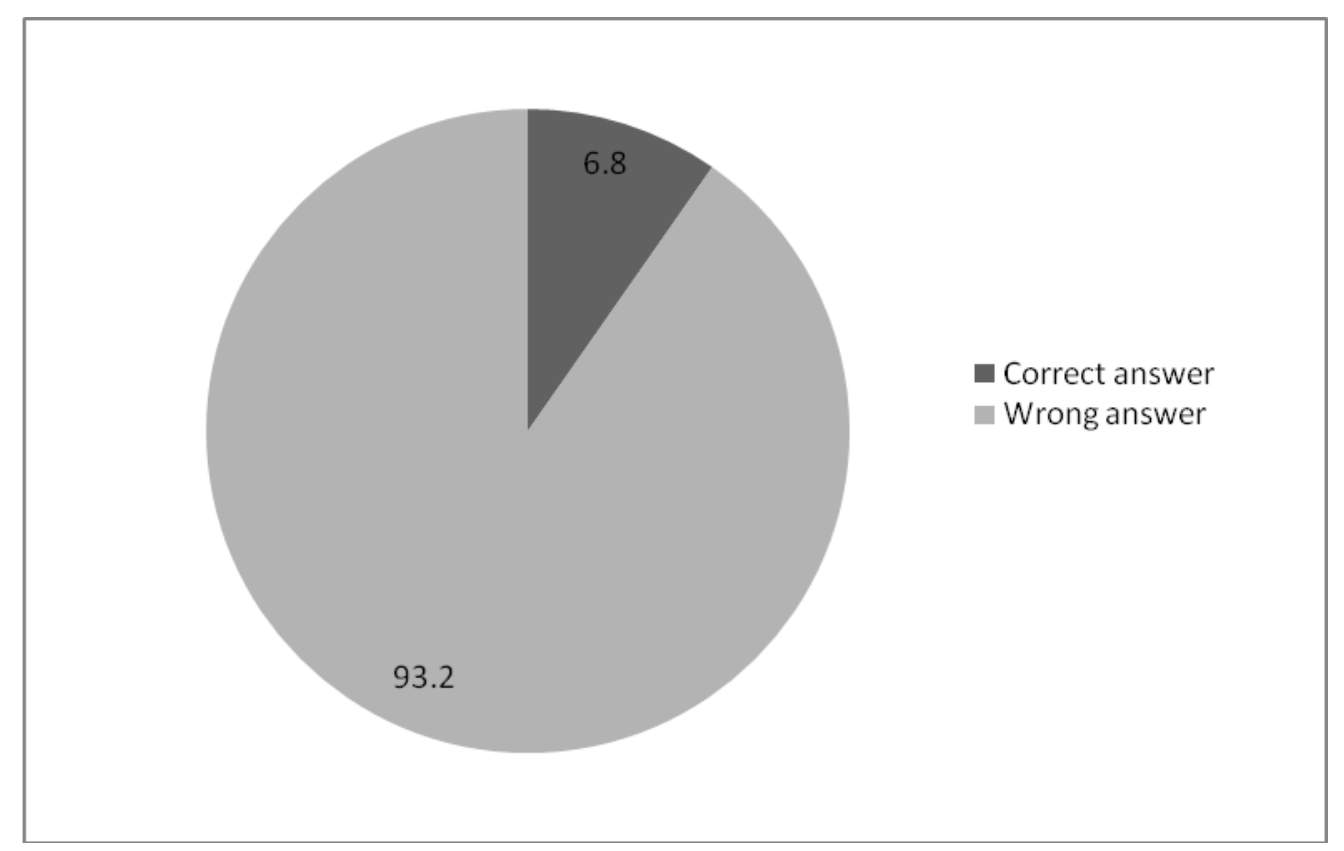

The result showed that only $6.8 \%(n=60)$ respondents answered the question correctly i.e. 3 months to 1 year for doing Gap Year Volunteerism.

For the volunteer programme, students were given a list of agencies and they were asked if these agencies were involved in the Gap Year Volunteerism and to name the 7 pioneer universities which collaborated with the participating agencies. The results are illustrated in Table 3. 
INTERNATIONAL JOURNAL OF ACADEMIC RESEARCH IN BUSINESS AND SOCIAL SCIENCES

Vol. 9, No. 2, Feb, 2019, E-ISSN: 222 2-6990 @ 2019 HRMARS

Table 3: Agencies and universities involved in the Gap Year Volunteerism

\begin{tabular}{|c|c|c|}
\hline Agencies & $\begin{array}{l}\text { Correct } \\
\text { answer }\end{array}$ & Universities \\
\hline Islamic Relief Malaysia & $\begin{array}{c}6.3 \% \\
(n=56)\end{array}$ & $\begin{array}{l}\text { Universiti Sains Islam Malaysia. Only one } \\
\text { respondent named the university correctly. }\end{array}$ \\
\hline $\begin{array}{l}\text { Ministry of Education and } \\
\text { Perak Education Department }\end{array}$ & $\begin{array}{c}6.5 \% \\
(n=58)\end{array}$ & $\begin{array}{l}\text { Universiti Pendidikan Sultan Idris. Only } 53 \\
\text { respondents named the university correctly. }\end{array}$ \\
\hline Welfare Department & $\begin{array}{c}3.4 \% \\
(n=30)\end{array}$ & $\begin{array}{l}\text { Universiti Utara Malaysia. Only } 10 \text { students } \\
\text { named the university correctly. }\end{array}$ \\
\hline $\begin{array}{l}\text { Department of Orang Asli } \\
\text { Development }\end{array}$ & $\begin{array}{c}3.3 \% \\
(n=29)\end{array}$ & $\begin{array}{l}\text { Universiti Sultan Zainal Abidin. Only } 19 \text { students } \\
\text { named the university correctly. }\end{array}$ \\
\hline $\begin{array}{l}\text { National Disaster } \\
\text { Management Agency }\end{array}$ & $\begin{array}{c}2.4 \% \\
(n=21)\end{array}$ & $\begin{array}{l}\text { Universiti Malaysia Terangganu. Only } 14 \text { students } \\
\text { named the university correctly. }\end{array}$ \\
\hline Kota Kinabalu City Hall & $\begin{array}{c}5.2 \% \\
(n=46)\end{array}$ & $\begin{array}{l}\text { Universiti Malaysia Sabah. Only } 44 \text { students } \\
\text { named the university correctly. }\end{array}$ \\
\hline State Welfare Department & $\begin{array}{c}3.9 \% \\
(n=35)\end{array}$ & $\begin{array}{l}\text { Universiti Tun Hussein Onn Malaysia. Only } 10 \\
\text { students named the university correctly. }\end{array}$ \\
\hline
\end{tabular}

The results in Table 3 showed that less than 10\% of the respondents could answer the participating agencies and the 7 pioneer universities that collaborated with the participating agencies correctly.

The next section in knowledge asked about the General Gap Year. The students were asked about the length of programme. The result is shown in Figure 4. 


\section{Figure 4: General Gap Year programme length}

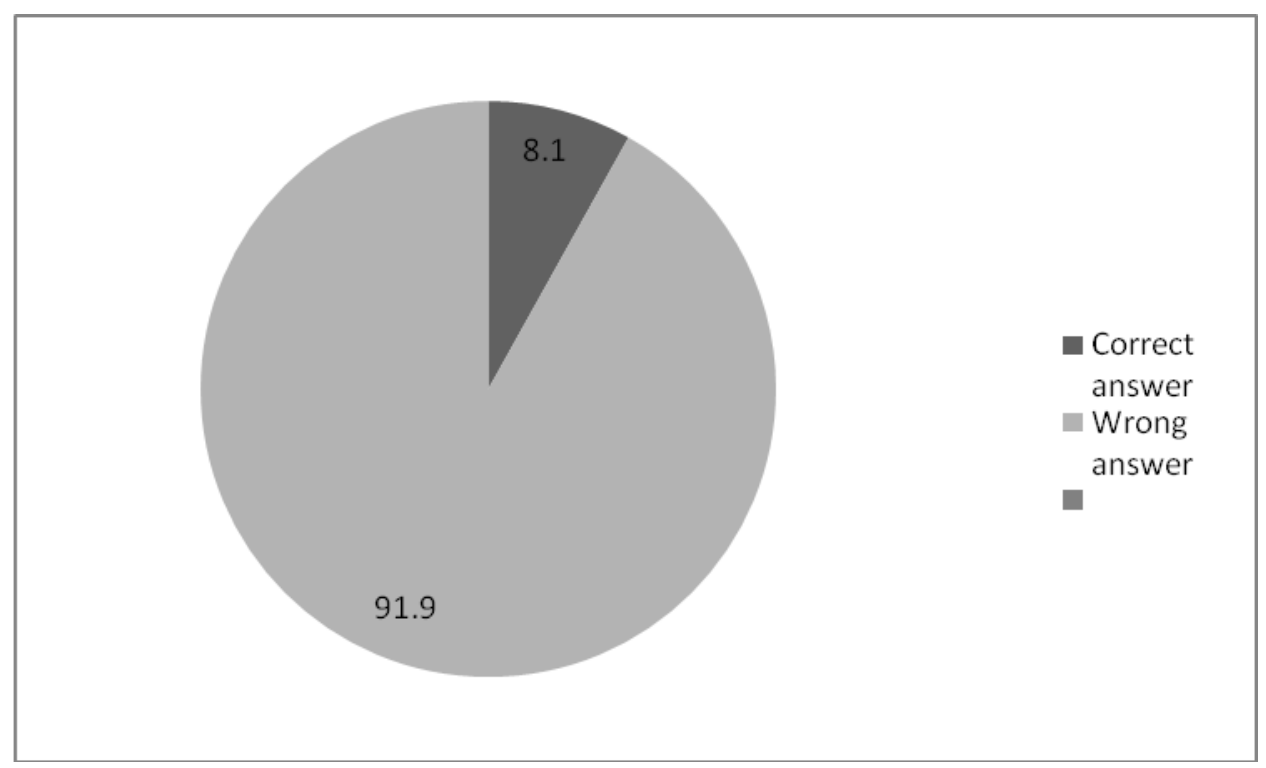

The result showed that only $8.1 \%(n=72)$ respondents answered the question correctly i.e. one semester to one year for doing General Gap Year programme.

In this section, students were asked about the activities that they can do for the General Gap Year programme. The responses are illustated in Table 4.

Table 4: Activities for the General Gap Year programme

\begin{tabular}{lcc}
\hline Activities & Frequency & $\%$ \\
\hline Sports & 229 & 25.8 \\
Entrepreneurship & 319 & 36 \\
Increase skills & 346 & 39 \\
Vacation & 156 & 17.6 \\
\hline
\end{tabular}

Table 4 shows that a number of students knew the activities that they could do in the General Gap year. However, the majority of students were not sure about the activities in the General Gap year programme.

The last section asked about requirements to join the Gap Year programme. The findings are shown in Table 5. 
Table 5: Requirements for Gap Year programme

\begin{tabular}{|c|c|c|c|c|}
\hline & $\begin{array}{l}\text { Yes } \\
(\%)\end{array}$ & $\begin{array}{l}\text { No } \\
(\%)\end{array}$ & $\begin{array}{c}\text { Don't know } \\
(\%)\end{array}$ & Correct answer \\
\hline $\begin{array}{l}\text { All students including international students } \\
\text { can join the programme }\end{array}$ & 67.1 & 27.1 & 5.9 & No \\
\hline Students at public university only & 66.5 & 24 & 9.5 & Yes \\
\hline $\begin{array}{l}\text { First year students can apply for Gap Year } \\
\text { programme }\end{array}$ & 71.3 & 21.6 & 7.1 & No \\
\hline $\begin{array}{l}\text { Students can join Gap Year programme more } \\
\text { than one time throughout their study }\end{array}$ & 76.8 & 12.4 & 10.8 & No \\
\hline
\end{tabular}

As shown in Table 5, the results showed that only $27.1 \%$ of the respondents knew that the programme was available for Malaysian students only. More than half knew that the programme was for students enrolled at the public universities only. Less than a quarter of the students knew that first-year students could not apply for the programme and they could only join once throughout their study.

\section{Attitude}

In this study, the attitude among respondents was investigated by responses to five questions towards the Gap Year programme. As shown in Table 6, the results showed that overall, the respondents had positive attitudes about the Gap Year programme.

Table 6: Attitudes towards the Gap Year programme.

\begin{tabular}{lcc}
\hline & Mean & SD \\
\hline I am confident Gap Year programme can improve student's soft skills & 3.74 & 0.94 \\
Joining Gap Year programme will not affect me to graduate on time & 3.19 & 1.08 \\
Gap Year programme promotes responsible culture, patriotism, caring & 3.78 & 0.90 \\
and volunteer culture & & \\
Gap Year programme can increase students' employability & 3.71 & 0.92 \\
Gap Year programme enriches students' lives to become a holistic and & 3.76 & 0.93 \\
useful student in the society & & \\
All students should take the opportunity to join Gap Year programme & 3.19 & 1.07 \\
\hline
\end{tabular}

\section{Discussion and Conclusion}

The analysis demonstrated that the respondents in this study had very limited knowledge about Gap Year programme. Very few students knew the details of the programme such as the type of 
programmes, the pioneer universities, the length of the programme and the agencies involved. The fact that the Gap Year was a newly launched concept in Malaysia (which started in September 2017), unlike in the UK or Australia where the concept is popular (Abidi, 2004 and Birch \& Miller, 2007), could be the reason why the programme was not well-known by many students at the university. However, although the respondents had limited knowledge about Gap Year programme, their attitudes towards the programme were positive. This is evident by the mean values of the attitudes' items, where they ranged from 3.19 to 3.78. These positives attitudes were similar to previous studies abroad. In Hulstrand (2010) study, it was found that Gap Year was a great way for students to learn about their individual interests and their career pursuits, help students mature and choose the right path. In another study, it was found that students involved in the Gap Year can acquire a range of benefits from the transformative experience including the acquisition of soft skills and cross-cultural experience in a host country (Jones, 2005), significant gains in personal, civic, moral and intellectual development (O'Shea, 2011), developing confidence, maturity and independence (King, 2011).

The growth of gap years over the decades reflects wider opportunities for young people to develop their skills and potential. Gap year should be seen as an opportunity for young people to become more mature and holistic graduate, which can increase their employability and networking. The findings of this study provide some insight for the university and ministry about the students' knowledge and attitudes toward the Gap Year programme. Based on this finding, Malaysian universities should conduct more awareness programmes to make more students aware of the existence of Gap programme. Both the university and the ministry should identify and use the medium that is popular among students to ensure that the information reaches the target audience; as such, this can increase their knowledge about Gap Year programme, as well as the benefits of joining the programme. Future studies could be conducted in other public universities to get a more holistic view and the results can be generalized to a larger group.

\section{Acknowledgement}

This research is funded by Universiti Pendidikan Sultan Idris Research Grant (2017-0161-106-01)

\section{Corresponding Author}

Suriani Abdul Hamid

Senior Lecturer

Universiti Pendidikan Sultan Idris

35900, Tanjung Malim, Perak

Malaysia

Email: suriani@fpe.upsi.edu.my

\section{References}

Abidi, Z. (2004). Taking a gap year?. London, YMCA George Williams College for the Rank Foundation. 
INTERNATIONAL JOURNAL OF ACADEMIC RESEARCH IN BUSINESS AND SOCIAL SCIENCES

Vol. 9, No. 2, Feb, 2019, E-ISSN: 222 2-6990 @ 2019 HRMARS

Birch, E.R. \& Miller, P.W. (2007). The characteristics of gap year students and their tertiary academics outcome, Economic Record, 83 (262), 329-344.

Cremin, C. (2007). Living and really living: The gap year and the commodification of the contigent, Ephemera, 7 (4), 526-542.

Garis panduan Gap Yea.(2017. Kementerian Pendidikan Tinggi.

Grose, T. K. (2010). The lure of the gap year: Time of learning and maturing can mean refreshed batteries and prepared students, U.S News and World Report.

Guidi, C. (2018). Experiencing a Gap Year: Perceptions from Students in the United States (Unpublished doctoral dissertation), College of Professional Studies Northeastern University Boston, Massachusetts.

Heath, S. (2007). Widening the gap: pre-university gap years and the economy of experience, British Journal of Sociology of Education, 28 (1), 89-103.

Haighler, K. \& Nelson, R. (2005). Gap year American Style, Journeys toward learning, serving and self-discovery.

Hulstrand, J. (2010). Time out: The gap year abroad, International Educator, Mar/Apr 2010: 19(2), 50-53

Jones, A. (2004). Review of gap Year Provision, London, UK Departmemt for Education and Skills. Retrieved from http://www.tussenjaartwijfels.info/wpcontent/uploads/2015/07/AndrewJonesforDfES2003.pdf

King, A. (2011). Minding the gap? Young people's accounts of taking a Gap Year as a form of identity work in higher education, Journal of Youth Studies, 14 (3), 341-357.

Malaysia Education Blueprint (Higher Education 2015-2025). (2015). Ministry of Higher Education Malaysia.

Nieman, M.M. (2013). South African students' perceptions of the role of a gap year in preparing them for higher education, African Education Review, 10 (1), 132-147.

O'Shea, J. (2011). Delaying academy; A gap year education, Teaching in Higher Education, 16(5), 565-577.

Stehlik, T. (2010). Mind the gap: school leaver aspirations and delayed pathways to further and higher education, Journal of Education and Work, 23 (4), 363-376.

Tucker, J. (2012). College students fill gap year with meaning, SF Gate, September.

Torpey, E.M. (2009). Gap year: Time off with plan, Occupational Outlook Quarterly, Fall, 26-33.

US Fed New Service. (2016). Florida State University kicks off inaugural year of gap year fellowship program, Washington D.C.

Wu, M.Y., Pearce, P., Huang, K. \& Fang, T. (2015). Gap year in China: views from the participants and implications for the future, Current Issues in Tourism, 18 (2), 158-174. 